\title{
IMPLEMENTATION OF MUNICIPAL LAND CONTROL IN VOLGOGRAD
}

\author{
N.V. Saushkina \\ Volgograd State Agricultural University \\ Volgograd, 400002, Russian Federation \\ nadezhda-rakitina@yandex.ru
}

\begin{abstract}
Identifying the main land legislation violations in Volgograd is a prerequisite for the preservation and rational use of the territory. The measures system development aimed at improving the effectiveness and efficiency of the municipal land control implementation will contribute to the city district main wealth preservation. The article presents the activities of specially authorized organizations and bodies for the land legislation observance. The average workload per 1 specialist in municipal land control carrying out amounted to 1.4 of inspections carried out for legal entities. The sequence of actions during the scheduled and out-of-scheduled inspections is given here. The report on the municipal land control carrying out in Volgograd for 2016 - 2017 is submitted. According to the land control results in 2016, from the total number of carried out inspections, $16.5 \%$ of them were revealed with violations, and in 2017 25.7\%. Amount of the prescribed fines in 2017 increased by more than twice in relation to 2016. Violations of land legislation in Volgograd occurred on the unauthorized occupation of land plots and their parts, the failure to comply with legal regulations on the violations elimination, the use of land not in accordance with its permitted use. Municipal land control was carried out in compliance with the general principles, duties, restrictions and prohibitions in carrying out control measures, as well as the requirements for processing the results of inspections. On the basis of the material reviewed, suggestions were made to improve the effectiveness and efficiency of the municipal and state land control implementation.
\end{abstract}

Key words: municipal land control, scheduled inspections, out-of-scheduled inspections, inspector, violations of land legislation

\section{INTRODUCTION}

In Russia, ensuring land protection and its rational use is the main goal in the field of land transformations. A necessary tool for performing tasks is land control over the protection and use of land at various structural levels. For violations in the field of land relations, a special role is assigned to administrative responsibility, which is an indicator of the state's reaction to the land legislation violators' actions. The essence of this responsibility lies in the application of administrative measures established and enshrined in the land legislation, to the guilty subject in violation of legal norms regarding the protection and land use, as well as the land users, landholders and landowners rights.

The department of municipal land control of the Volgograd administration municipal property department carries out municipal land control in Volgograd.

There are 8 officials (inspectors) in this department who are responsible for carrying out inspections in the Volgograd administrative districts. Accordingly, each inspector is assigned a specific area for the land control implementation at the municipal level [1].

The goal of the research is to consider and analyze the process of municipal land control implementation in Volgograd. 


\section{MATERIALS AND METHODS}

The land control implementation is divided into several stages, which are the administrative procedures presented in Figure 1.

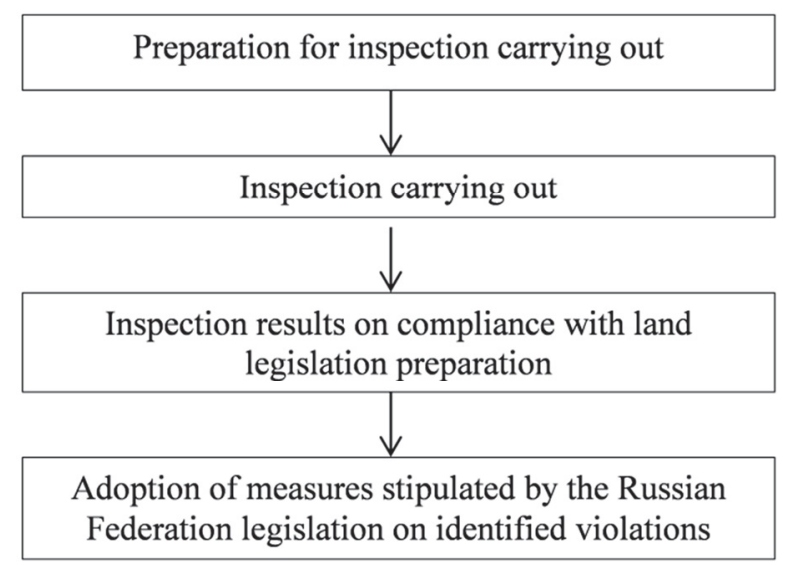

Fig. 1. Scheme of administrative procedures

In order to implement land control, scheduled and out-of-scheduled inspections are carried out [2]. In Figure 2 we consider in details the organization and rules for carrying out scheduled inspections.

When carrying out planned inspections, they observe the land legislation in respect of legal entities and individual entrepreneurs and carry them out no more often than once every three years.

Scheduled inspections are carried out in accordance with the annual inspection plan.

The regular scheduled inspections inclusion in the annual plan for inspections of legal entities and individual entrepreneurs is carried out in connection with the expiration of 3 years from the day of:

1) the legal entity or an individual entrepreneur state registration, or the start of a legal activity;

2) the end of the last scheduled inspection.

In due time, the Federal Service for State Registration, Cadaster and Cartography and its territorial bodies send annual plans drafts to the prosecutor's office. The prosecutor's office considers and makes proposals to eliminate the detected comments, and also makes additional proposals for carrying out joint inspections with the land control authorities.

The approved inspection plan is communicated to concerned parties by posting it on official websites or by other available means.

The total duration of the inspection (from the date of commencement to the date of drawing up the inspection report) may not exceed 20 working days. In relation to one small business entity, the total duration of a scheduled inspection cannot exceed 50 hours for a small enterprise and 15 hours for a micro-enterprise per year. 
Preparation of the inspections draft annual plan and sending it to the prosecutor's office (until September, 1 of the year preceding the year of the scheduled inspections)

Consideration of the inspections carrying out draft annual plan by the prosecutor's office and sending proposals for the plan amending (until October, 1 of the year preceding the year of the scheduled inspections)

Amendments to the annual plan, the plan approval by the land control authority head and the approved plan sending to the prosecutor's office (until November, 1 of the year preceding the year of the scheduled inspections)

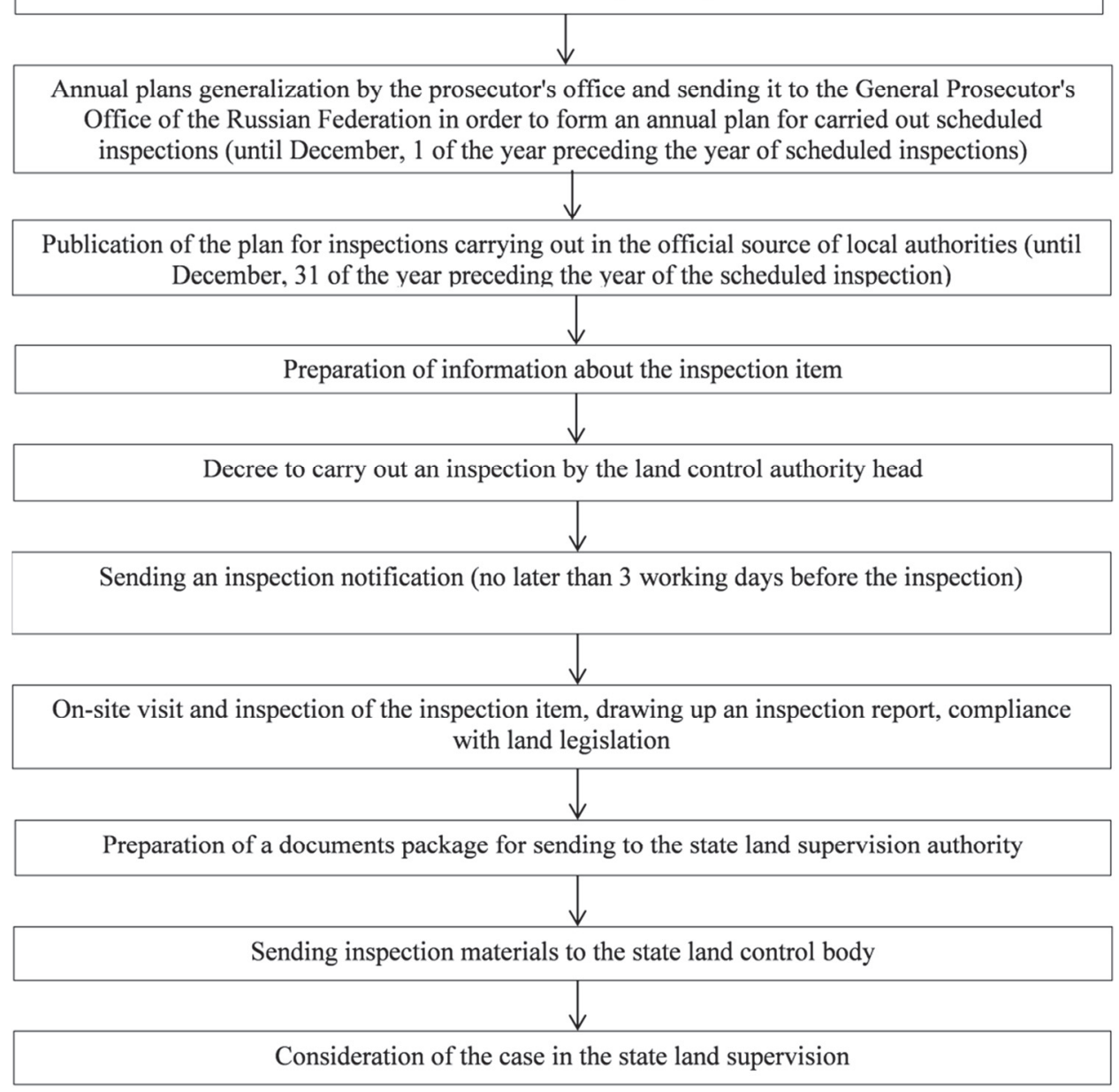

Fig. 2. The sequence of administrative procedures at implementation municipal land control when carrying out planned inspection

In exceptional cases, related to the need for a complex or lengthy research, testing, special investigations and examinations on the basis of proposals from the Federal Service for State Registration, Cadaster and Cartography officials carrying out a scheduled inspection, the period of an on-site scheduled inspection can be extended by the Chief Inspector, but not more than 20 working days for a small business, and not more than 15 hours for a micro-enterprise. 


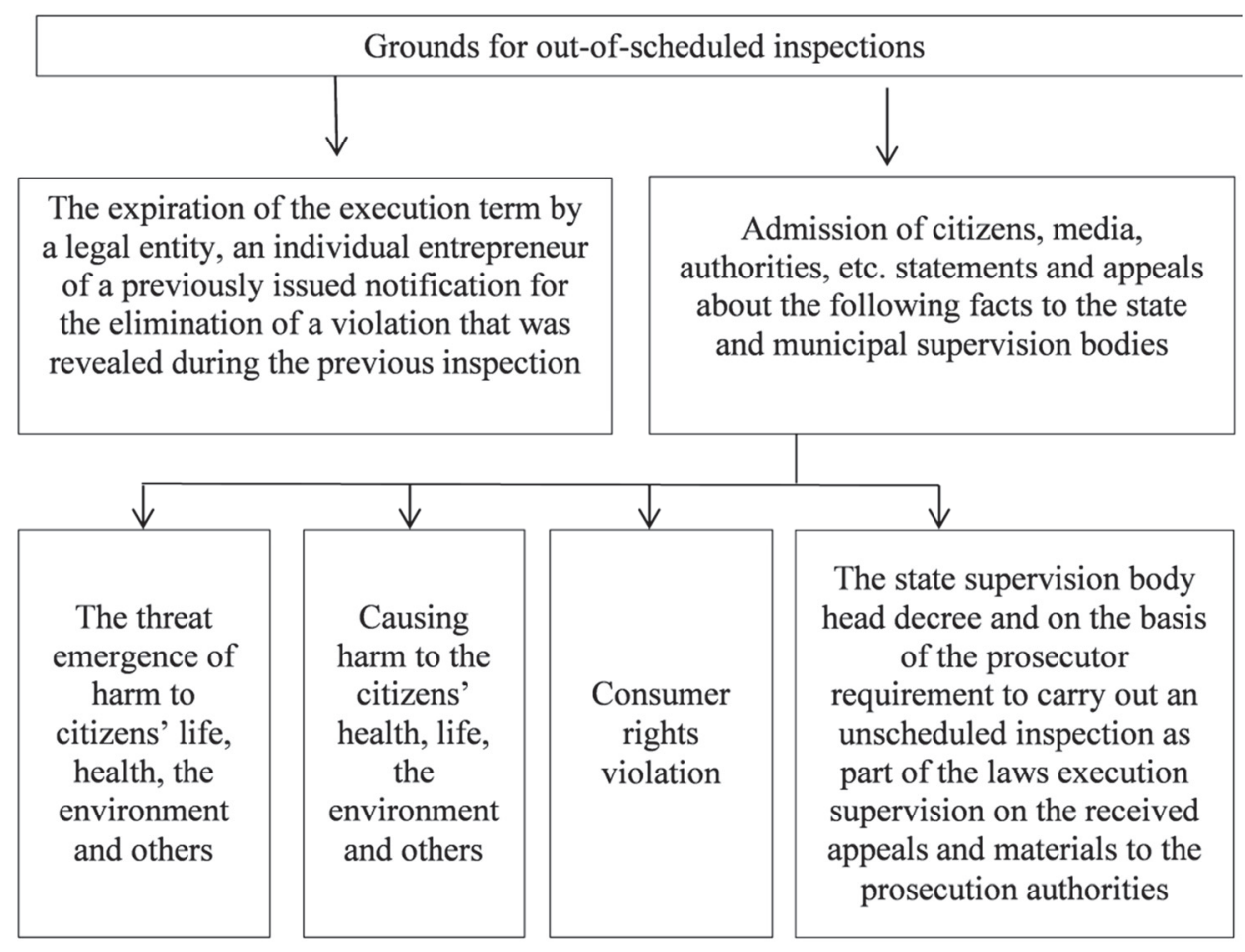

Fig. 3. Grounds for out-of-scheduled inspections carrying out

The inspected person is informed about the extension of the inspection period in writing, as well as by telephone or facsimile, e-mail no later than the day following the date of signing.

Let us turn to the organization of an out-of-scheduled inspection in Figure 3.

The subject of an out-of-scheduled inspection is compliance with the mandatory requirements in the activities implementation, compliance with the requirements of Federal Service for State Registration, Cadaster and Cartography, measures to prevent harm to citizens' life and health, the environment, etc.

Applications and appeals that do not allow to identify a person who has applied to the body of state or municipal supervision, as well as appeals and statements that do not contain information about the facts, cannot serve as the basis for an out-ofscheduled inspection carrying out.

An out-of-scheduled inspection is carried out in the form of a documentary inspection or an on-site inspection.

The procedure for the approval of the state and municipal supervision with the prosecutor's office of an out-of-scheduled on-site inspection is established by the Russian Federation Prosecutor General order.

In Figure 4, we consider a phased procedure for out-of-scheduled inspections carrying out and documents preparation.

On the day of prescription, the decree to carry out an out-of-scheduled on-site inspection is sent by registered mail with a statement of receipt or in the form of an electronic document signed by an enhanced qualified electronic signature on the application for an out-of-scheduled on-site inspection approval. 


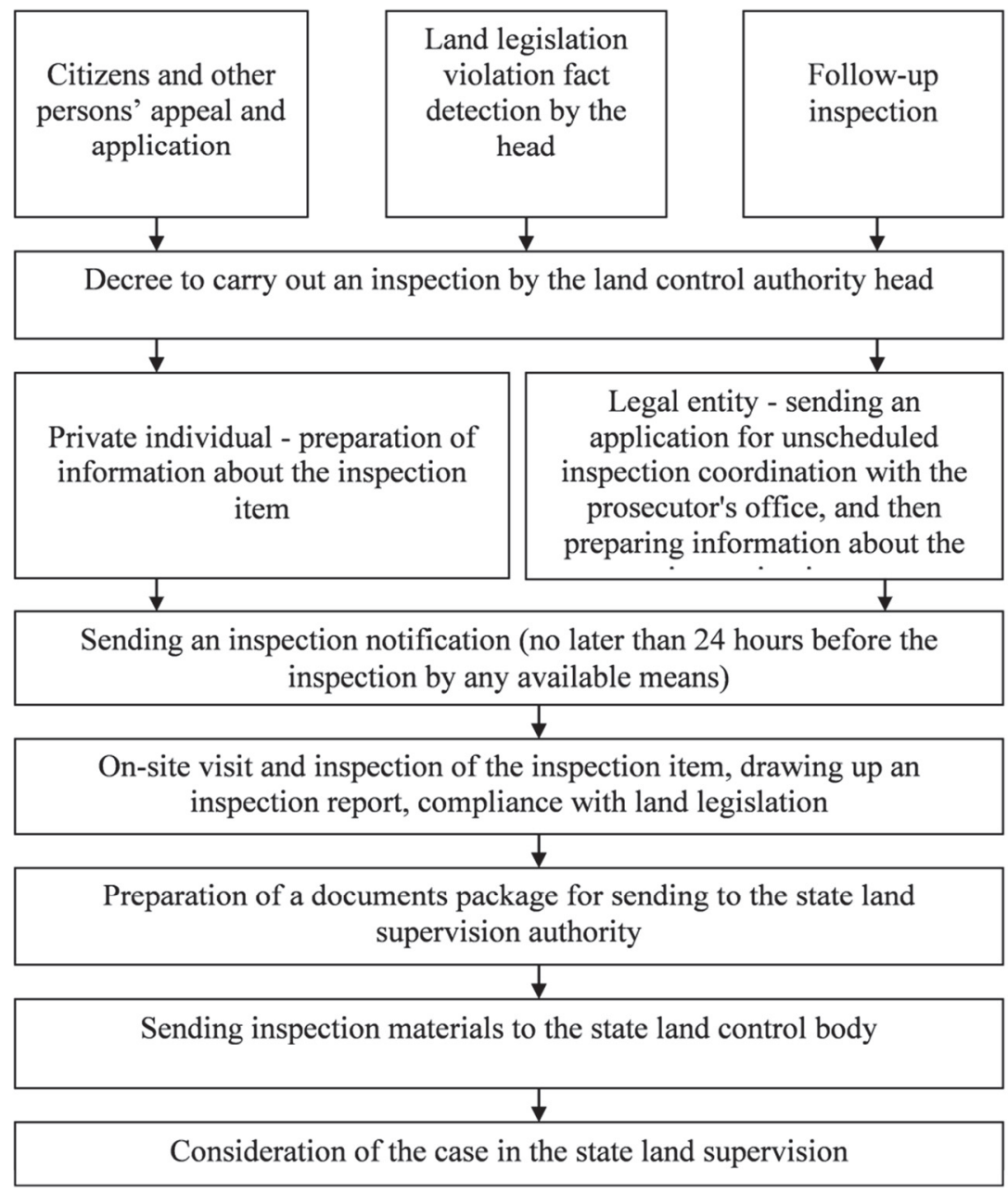

Fig. 4. The sequence of administrative procedures at municipal land control implementation when out-of-scheduled inspection carrying out land use.

Now let us consider the bodies and organizations that exercise control over the

Specialists and officials carry out state land control in accordance with the prescribed procedure in the resolution approving the on state land supervision provision [4]. Specially authorized bodies are the Federal Service for State Registration, Cadaster and Cartography, the Federal Service for the Supervision of Natural Resources and the Federal Service for Veterinary and Phytosanitary Supervision.

Officials and specialists in accordance with the legislation of the Russian Federation and the adopted regulatory and legal acts of local self-government bodies carry out municipal land control.

The specially authorized body exercising municipal land control in Volgograd is the Department of Municipal Property of the Administration of Volgograd. The main regulations for this control type implementation in Volgograd is the decision of the city administration on the administrative regulations for the implementation of municipal land control [5]. 
The average workload per 1 specialist in municipal land control carrying out amounted to 1.4 of inspections carried out for legal entities, individual entrepreneurs per year (including: in the first half of the year - 0.8 of inspections for a specialist, in the second half-year - 0.6 of inspections for 1 specialist).

In 2016, in Volgograd, municipal land control was carried out in respect of 1 legal entity and 96 citizens. It was not possible to carry out scheduled inspections of 46 citizens for reasons of the ownership change, lack of attendance and the impossibility of notifying the inspected ones about the forthcoming inspection (Table 1). In 2017, the department specialists carried out: 88 scheduled inspections, out-of-scheduled inspections in relation to individuals; participated in 39 inspections carried out in relation to economic entities; 4911 surveys, land surveys for their actual use.

Table 1

\section{Report on municipal land control carrying out}

\begin{tabular}{|c|c|c|c|c|c|c|c|c|c|c|}
\hline & \multicolumn{3}{|c|}{$\begin{array}{c}\text { Inspections } \\
\text { (all on-site inspec- } \\
\text { tions) }\end{array}$} & \multicolumn{5}{|c|}{ Inspections' results } & \multirow{3}{*}{$\begin{array}{c}\text { Failed } \\
\\
\\
\text { part 1 } \\
\text { art. 19.4.1 }\end{array}$} & \multirow[t]{3}{*}{$\begin{array}{l}\text { Imposed } \\
\text { fines, } \\
\text { units/rub. }\end{array}$} \\
\hline & \multirow[t]{2}{*}{ total } & \multirow{2}{*}{$\begin{array}{l}\text { sche- } \\
\text { duled }\end{array}$} & \multirow{2}{*}{$\begin{array}{l}\text { out-of- } \\
\text { sche- } \\
\text { duled }\end{array}$} & \multirow{2}{*}{$\begin{array}{l}\text { without } \\
\text { viola- } \\
\text { tions }\end{array}$} & \multicolumn{4}{|c|}{ With violations (AOC RF) } & & \\
\hline & & & & & total & art. 7.1 & $\begin{array}{c}\text { part } 1 \\
\text { art. } 8.8\end{array}$ & $\begin{array}{c}\text { part } 1 \\
\text { art. } 19.5\end{array}$ & & \\
\hline \multicolumn{11}{|c|}{2016} \\
\hline Legal entities & 1 & - & 1 & 1 & - & - & - & - & - & - \\
\hline Citizens & 96 & 67 & 29 & 74 & 22 & 13 & 3 & 6 & 6 & $18 / 76700$ \\
\hline Total & 97 & 67 & 30 & 75 & 16 & 13 & 3 & 6 & 6 & $18 / 76700$ \\
\hline \multicolumn{11}{|c|}{2017} \\
\hline Legal entities & 13 & 12 & 1 & 10 & 3 & 2 & - & 1 & - & $1 / 100000$ \\
\hline Citizens & 88 & 64 & 24 & 65 & 23 & 17 & 1 & 5 & 6 & $22 / 77900$ \\
\hline Total & 101 & 76 & 25 & 75 & 26 & 19 & 1 & 6 & 6 & $23 / 177900$ \\
\hline
\end{tabular}

According to the inspections plan for 2017, 76 on-site inspections were approved, of which 12 are against legal entities and 64 are against citizens. In addition, the Volgograd municipal land control department specialists carried out 24 out-of-scheduled inspections of citizens and 1 out-of-scheduled inspection of a legal entity, the data are presented in table 1 .

In 2016, following the results of the inspections included in the plan for this year, 22 violations of land legislation by citizens were revealed, most of which unauthorized occupied the land plot or its part. In 2016, 13 citizens were brought to administrative responsibility, and fines totaling 76700 rubles were imposed.

In 2017, following the results of the municipal land control in 2017, violations were revealed in relation to 3 legal entities and 23 citizens, 177900 rubles were imposed for the violation of the land legislation.

Violations of land legislation in Volgograd occurred on the unauthorized occupation of land plots and their parts, the failure to comply with legal regulations on the elimination of violations, the use of land not in accordance with its permitted use. 


\section{CONCLUSIONS}

Municipal land control is carried out in compliance with the general principles, duties, restrictions and prohibitions in carrying out control measures, as well as the requirements for processing the results of inspections.

In the period from 2016 to 2018, when carrying out the state control (supervision) and municipal control, no scheduled inspections were carried out with respect to legal entities and individual entrepreneurs related to small businesses.

The following can contribute to improve the effectiveness and efficiency of the municipal land control implementation:

1) regular implementation of practical seminars covering issues of interaction between municipal control bodies and state supervisory authorities;

2) increasing the size of fines imposed for land legislation administrative violation of.

In order to increase the efficiency of municipal control carrying out, it is necessary to transfer the authority to draw up protocols on land legislation administrative offenses to the level of municipalities.

\section{REFERENCES}

1. Volgograd administration official website. Volgograd administration department of municipal property: open data [Internet]. Available from: $\mathrm{http} / / / \mathrm{www}$. volgadmin.ru/d/branches/dmi/about.

2. Land Code: Federal Law № 136-FL of 25 October 2001 [Internet]. Available from: http://base.consultant.ru/document/cons_doc_LAW_33/.

3. Federal law of Russian Federation № 294-FL of 26 December 2008 “O zashchite prav yuridicheskikh lits i individual'nykh predprinimatelei pri osushchestvlenii gosudarstvennogo kontrolya (nadzora) i munitsipal'nogo kontrolya". Available from: http://www.consultant.ru/document/ cons_doc_LAW_83079/.

4. Russian Federation Government Decree № 1 of 2 January 2015 "Ob utverzhdenii polozheniya o gosudarstvennom zemel'nom nadzore". Available from: http://base. consultant.ru/document/ cons_doc_LAW_173212/.

5. Decree of the Volgograd Region Administration № 376-d of 13 July 2015 “Ob utverzhdenii Poryadka osushchestvleniya munitsipal'nogo zemel'nogo kontrolya na territorii Volgogradskoi oblasti". Available from: http://base.garant.ru/24811143/.

\section{INFORMATION ABOUT AUTHORS}

Saushkina Nadezhda Viktorovna - Candidate of Agricultural Sciences, Volgograd State Agricultural University, e-mail: nadezhda-rakitina@yandex.ru

\section{For citation:}

Saushkina NV. Implementation of municipal land control in Volgograd. RUDN Journal of Agronomy and Animal Industries, 2018, 13 (4), 344-352. doi: 10.22363/2312-797X-2018-13-4-344-352. 


\title{
ОСУЩЕСТВЛЕНИЕ МУНИЦИПАЛЬНОГО ЗЕМЕЛЬНОГО КОНТРОЛЯ НА ТЕРРИТОРИИ ГОРОДА ВОЛГОГРАДА
}

\author{
Н.В. Саушкина \\ Волгоградский государственный аграрный университет \\ Волгоград, Российская Федерация, 400002 \\ nadezhda-rakitina@yandex.ru
}

\begin{abstract}
Выявление основных нарушений земельного законодательства на территории города Волгограда является необходимым условием для сохранения и рационального использования территории. Разработка системы мероприятий, направленных на повышение результативности и эффективности осуществления муниципального земельного контроля, будет способствовать сохранению главного богатства городского округа. В статье представлена деятельность специально уполномоченных организаций и органов за соблюдением земельного законодательства. Средняя нагрузка на 1 специалиста по проведению муниципального земельного контроля составила 1,4 проверки. Приведена последовательность действий при проведении плановых и внеплановых проверок. Представлен отчет о проведении муниципального земельного контроля на территории города Волгограда за 20162017 годы. По результатам земельного контроля в 2016 году из общего числа проведенных проверок с нарушениями выявлено 16,5\%, а в 2017 году — 25,7\%. Сумма предписанных штрафов в 2017 году выросла больше чем в два раза по сравнению с 2016 годом. Нарушения земельного законодательства на территории города Волгоград приходились на самовольное занятие земельных участков и их частей, невыполнение законных предписаний об устранении нарушений, использование земельного участка не в соответствии с его разрешенным использованием. Муниципальный земельный контроль осуществляется с соблюдением общих принципов, обязанностей, ограничений и запретов при проведении мероприятий по контролю, а также требований к оформлению результатов проведения проверок. На основании рассмотренного материала приведены предложения для повышения результативности и эффективности осуществления муниципального и государственного земельного контроля.
\end{abstract}

Ключевые слова: муниципальный земельный контроль, плановые проверки, внеплановые проверки, инспектор, нарушения земельного законодательства

\section{БИБЛИОГРАФИЧЕСКИЙ СПИСОК}

1. Официальный сайт администрации города Волгоград. Департамент муниципального имущества администрации Волгограда: открытые данные [Электронный ресурс] // Официальный сайт администрации Волгограда. Режим доступа: http://www.volgadmin.ru/ d/branches/dmi/about.

2. Российская Федерация. Законы. Земельный кодекс: федеральный закон от 25.10.2001 № 136-Ф3 [Электронный ресурс] // СПС КонсультантПлюс. Режим доступа: http://base.consultant.ru/document/cons_doc_LAW_33/.

3. Российская Федерация. Законы. О защите прав юридических лиц и индивидуальных предпринимателей при осуществлении государственного контроля (надзора) и муниципального контроля [Электронный ресурс]: федеральный закон от 26.12.2008 № 294-ФЗ (в ред. от 03.08.2018 № 323-Ф3) // СПС КонсультантПлюс. Режим доступа: http://www.consultant.ru/ document/cons_doc_LAW_83079/.

4. Российская Федерация. Правительство. Об утверждении положения о государственном земельном надзоре: постановление Правительства РФ от 02.01.2015 № 1 [Электронный pecypc] // СПС КонсультантПлюс. Режим доступа http://base.consultant.ru/document/ cons_doc_LAW_173212/. 
5. Российская Федерация. Администрация Волгоградской области. Об утверждении Порядка осуществления муниципального земельного контроля на территории Волгоградской области: постановление администрации Волгоградской области от 13.07.2015 № 376-п [Электронный ресурс] // ГАРАНТ.ру. Режим доступа: http://base.garant.ru/24811143/.

\section{Для цитирования:}

Саушкина Н.В. Осуществление муниципального земельного контроля на территории города Волгограда // Вестник Российского университета дружбы народов. Серия: Агрономия и животноводство. 2018. Т. 13. № 4. С. 344 -352. doi: 10.22363/2312-797Х-2018-13-4-344-352. 